\title{
In vitro Modeling of Prion Strain Tropism
}

\author{
Etienne Levavasseur ${ }^{1,+}$, Nicolas Privat ${ }^{1,+}$ and Stéphane Haïk ${ }^{1,2, *(1)}$ \\ 1 Institut du Cerveau et de la Moelle épinière, ICM, Inserm U 1127, CNRS UMR 7225, Sorbonne Université, \\ 75013 Paris, France; etienne.levavasseur@icm-institute.org (E.L.); nicolas.privat@inserm.fr (N.P.) \\ 2 Assistance Publique-Hôpitaux de Paris, Cellule nationale de référence des MCJ, G.H. Pitié-Salpêtrière, 75013 \\ Paris, France, AP-HP, Laboratoire de Neuropathologie, G.H. Pitié-Salpêtrière, 75013 Paris, France \\ * Correspondence: stephane.haik@upmc.fr; Tel.: +33-157274515 \\ + Co-first authors.
}

Received: 31 January 2019; Accepted: 5 March 2019; Published: 9 March 2019

check for updates

\begin{abstract}
Prions are atypical infectious agents lacking genetic material. Yet, various strains have been isolated from animals and humans using experimental models. They are distinguished by the resulting pattern of disease, including the localization of PrPsc deposits and the spongiform changes they induce in the brain of affected individuals. In this paper, we discuss the emerging use of cellular and acellular models to decipher the mechanisms involved in the strain-specific targeting of distinct brain regions. Recent studies suggest that neuronal cultures, protein misfolding cyclic amplification, and combination of both approaches may be useful to explore this under-investigated but central domain of the prion field.
\end{abstract}

Keywords: models; prion; tropism

\section{Introduction}

Prion diseases are a group of rare progressive neurodegenerative disorders that affect both humans and animals. Scrapie in sheep and goats, bovine spongiform encephalopathy (BSE) in cattle, and chronic wasting disease (CWD) in wild ruminants such as cervids are the most common forms of the disease in animals. Humans are mainly affected by sporadic Creutzfeldt-Jakob disease (sCJD), while genetic and acquired forms of the disease such as Gerstmann-Sträussler-Scheinker syndrome and variant CJD, respectively, are much less frequent. The agents responsible for prion diseases are essentially composed of the abnormally folded form (PrPsc) of the host prion protein ( $\mathrm{PrPc}$ ) [1]. Among patients with SCJD, a wide range of clinical and neuropathological phenotypes has been observed. The molecular basis of such phenotypic diversity involves a methionine/valine (M/V) polymorphism at codon 129 of the prion protein gene (PRNP), combined with different folding patterns of the PrPsc that accumulates in the brain of affected individuals. The latter is reflected by different sizes of the residual, protease-resistant core fragments (PrPres) of PrPsc, which suggests different PK cleavage sites in the conformations of the protein [2]. The most widely used classification distinguishes two main subtypes of PrPres (PrPres type 1 with a migration of the un-glycosylated form of the protein at $21 \mathrm{kDa}$ and PrPres type 2 with a migration of the unglycosylated form of the protein at $19 \mathrm{kDa}$ ), as detected by the Western blot (WB) following digestion with proteinase-K (PK) [3-5]. Other researchers have proposed that an additional main type with an intermediate size of the un-glycosylated form can be detected in sporadic and iatrogenic CJD [6,7]. By correlating codon 129 genotype and PrPres types with clinical and pathological features in sporadic CJD, various molecular combinations corresponding to the most common phenotypic variants of SCJD were identified $[4,8]$.

Although they contain no nucleic acids, different prion strains can be propagated in experimental models [9]. The distribution of the accumulation of PrPsc in brain regions varies with the strain, which determines the tropism phenomenon. It is associated with a lesion profile that affects the clinical 
form. Two strains were originally observed after inoculating goats with different scrapie isolates [10]. Many other strains are now acknowledged [11]. In cattle, three BSE strains have been identified so far [12-14], and it seems that at least two different strains are responsible for CWD [15,16]. In humans, a growing number of strains are identified using experimental models susceptible to human prions such as knock-in mice expressing human PrP, bank vole, and non-human primates [12,17-19]. Several in vivo studies have been conducted to address the phenomenon of prion tropism that is central to the definition of strain. A few decades ago, it was shown that brain lesions occurred in a region-specific manner in animals inoculated intra-cranially or by the peripheral route with three scrapie strains (87A, 31A, and 125A) [20]. The stereotactic inoculation of 139A, ME7, and 22L scrapie strains directly into five specific brain regions in C57BL/6, revealed that the efficiency of the strain replication may vary with the inoculation site [21]. In humans, the two main SCJD subtypes MM1/MV1 and VV2a have been recently associated with different prion strains, by inoculation to non-human primates and to knock-in mice $[17,19,22]$. They are characterized by different clinical phenotypes and neuropathological profiles (early dementia, myoclonus, isocortical involvement in MM1-MV1, and ataxia, late dementia, and cerebellar involvement in VV2a). On the other hand, vCJD, which results from the transmission of the agent responsible for classical bovine spongiform encephalopathy to humans [12,23], is associated with a particular involvement of the posterior thalamus [24]. Transmission experiments demonstrated that the same prion strain is associated with the vCJD cases observed in different countries [18].

Despite such evidence of a strain-specific tropism leading to preferential replication in given brain regions, the cellular mechanisms involved in this phenomenon have been marginally studied in the field. In an experimental hamster model of mink encephalopathy, different neuronal populations are targeted according to the strain ("hyper" or "drowsy") that is inoculated into the sciatic nerve [25]. These first observations highlight the need for refined methods to address more precisely and specifically the strain tropism phenomenon. The recent development of cellular and acellular in vitro models of prion propagation has offered such an opportunity. In this case, we present and discuss the results obtained with primary neuronal cultures and protein misfolding cyclic amplification (PMCA). They provide the first evidence of a strain-specific neuronal tropism that may involve local molecular cofactors implicated in the PrP conversion process.

\section{Cellular Models of Prion Strain Tropism}

There are several prerequisites to investigate in vitro the strain-specific targeting of brain regions. First, from the point of view of cellular biology, a model permissive to different prion strains is mandatory. Research has long been limited by both the lack of available models and the poor infection level of cell cultures. Nonetheless, a number of assays have been designed by different laboratories (reviewed in Reference [26]). Highly susceptible sublines of N2a cells have been isolated and have proven useful as a rapid and sensitive alternative assay to the mouse bioassay for the detection of prions [27]. However, the scrapie cell assay remains restricted in its applicability since N2a sublines are resistant to prion strains of more immediate interest such as bovine or vCJD prions. In addition, immortalized cell lines derived from a malignant tumor are poorly relevant to study neuron-specific prion propagation that may vary with the precise neuroanatomical origin of the neuronal population. Based on primary cultures of cerebellar granular neurons from transgenic mice overexpressing ovine PrPc (tg338), a model of ovine prion propagation has been developed by Cronier et al [28]. Their results suggest that primarily grown cerebellar astrocytes (CAS) and cerebellar granular neurons (CGN) are permissive to PrPsc propagation. A similar system was subsequently developed with primary cultures of neurons from transgenic mice overexpressing human PrPc that were infected with a strain of sCJD, which was previously adapted to the same transgenic mouse line [29]. The results suggest that the anti-prion activity of three generic compounds (MS-8209, Congo red, chlorpromazine) observed in neuronal cultures is species-dependent or strain-dependent and recapitulates to some extent the activity reported in vivo in rodent models. Another in vitro model relies on cultured organotypic cerebellar slices (COCS) that can be infected with different prion strains (RML, 22L, and 139A) [30]. 
Prion-infected COCS reproduce the prion replication, inflammatory response, spongiform changes, and neurodegeneration observed in prion diseases.

Altogether, these studies suggest the feasibility of studying the cerebral tropism of prion strain using in vitro cellular models. To further decipher the mechanisms underlying the cerebral prion strain tropism, we set up primary neuronal cultures from cortex, striatum, and cerebellum of C57BL/ 6 mice. We showed that the kinetics of replication of three experimental scrapie strains stabilized in C57BL/6 mice (22L, ME7, 139A) differ with (i) the strain for a given model of cell culture, and (ii) the model of the cell culture for a given prion strain. Our results support the existence of a strain-specific neuronal tropism [31]. Furthermore, they show that a complex event such as the uncoupling of prion replication and toxicity that has been observed in mice [32] is reproduced in this model. The neurotoxic phase was initiated when a steady state of PrPres level was reached. This kinetics varied in a strain-dependent and neuronal-dependent manner. For instance, in granule cell cultures, the most cerebellar strain (22L) leading to granular cell loss in infected mice reached the plateau first with a more intense neuronal loss as compared to other strains.

In a second study, we propagated iatrogenic CJD (MM1 type), vCJD and SCJD (MM1) isolates in CGN cultures from mice overexpressing human M129 PrP, and a sCJD (VV2) isolate in CGN cultures overexpressing human V129 PrP [33]. Human prion propagation occurred at a later stage compared with CGN cultures infected with experimental scrapie strains [31]. In addition, different kinetics of prion propagation were observed between isolates in M129 PrP-CGN cultures suggesting a strain-specific neuronal tropism. Our results provided the first evidence supporting that human prion isolates could be propagated in primary cell cultures. This is an important step toward the search for chemical compounds targeting human prions, and the study of the cellular mechanisms involved in their brain distribution.

These different studies addressing the strain tropism phenomenon in cellular models share some limitations. (i) Primary cultures are usually established at embryonic stages, which might be an issue regarding the expression of cofactors. (ii) They are not fully representative of the cell populations present in the investigated brain region. (iii) The time-frame is limited and spontaneous degeneration and glial alterations may occur with time. (iv) A number of established models do not express an endogenous level of PrPc and have been transfected with the PRNP gene, which usually induces an overexpression of the protein.

In addition, developing a human cellular model susceptible to human isolates is a challenge for the years to come. Using a staggered exposure protocol, a recent study suggested that cultures of astrocytes derived from human induced pluripotent stem cells (iPSCs) are able to replicate CJD isolates in cells of human origin [34]. However, cultures of astrocytes may not be the most relevant model to address the strain tropism phenomenon. Although a heterogeneity of astrocytes based on morphological type is acknowledged [35]. Astrocyte cultures derived from iPSCs lack brain regional specificity. Developing human derived cell co-cultures including neuronal cells of different subtypes, astrocytes, and other cell types such as microglia [36] may provide useful models to study the complex interplay governing the differential strain-specific replication observed in some areas of the central nervous system.

\section{Acellular Models of Prion Strain Tropism}

Several laboratories have attempted to develop acellular systems reproducing in vitro the conversion of PrPc into PrPsc observed in vivo [37]. In 2001, the development of the protein mis-folding cyclic amplification (PMCA) opened the way for in vitro production of infectious prion proteins [38-41]. This system allows an exponential amplification of PrPsc using cyclic sonication and incubation, which is conceptually analogous to the amplification of DNA by PCR (Scheme 1). 


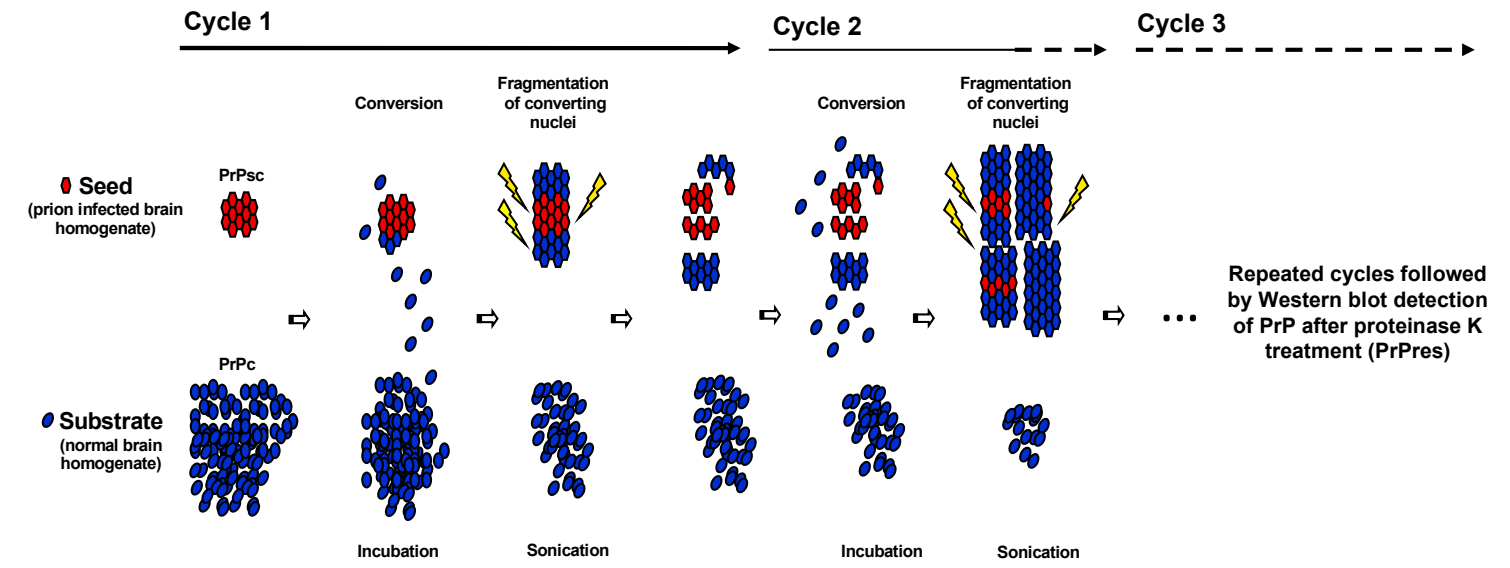

Scheme 1. Schematic representation of protein mis-folding cyclic amplification (PMCA). Principle of PMCA. Using PrPsc from infected brain homogenate as seed and an excess of PrPc from normal brain homogenate as substrate, PMCA, conducted in a cyclic manner, is able to amplify converting nuclei.

In addition, the PMCA products retain the main characteristics of the original PrPsc such as electrophoretic mobility, glycosylation pattern, and resistance to proteinase K [38-40,42,43]. Importantly, PrPsc generated by PMCA is infectious when inoculated to wild type animals [39,41,42]. PMCA allows studies on genotypic and species barrier of prion transmission [44-52], the detection of PrPsc in various biological fluids (blood, urine, saliva, LCR) [53-58], de novo generation of prions [59-61], and the identification of cofactors involved in PrP conversion [59,61-73]. To overcome some of the above-mentioned issues specific to cellular models, and to assess whether strain tropism can be studied in an acellular system, we recently developed a region-specific PMCA (rsPMCA) [46]. This technique allowed the use of various animal and human tissues, prepared from adult individuals. In addition, the tissue lysates used as substrates contain all the molecular factors of the different cell types and the extracellular space that are present in each brain structure (Scheme 2). The development of rsPMCA intended to assess whether prion strain tropism involves region-specific molecular factors.

We first compared the distribution of PrPres in five brain regions from C57BL/ 6 and tg650 (M129) mice intra-cerebrally inoculated with three different scrapie strains and VCJD, respectively, with the level of amplification by rsPMCA using the same regions taken from healthy animals as substrates [46]. Our results showed that rsPMCA partly matched, in the murine context, the regional targeting observed in vivo with 139A, ME7, 22L, and vCJD strains. Then, using normal human brain tissues from subjects with an MM or VV genotype at codon 129 as substrates, we confirmed these results with PrPsc from vCJD and SCJD VV2 isolates as seeds. When the results obtained using animal and human substrates were pooled, a highly significant correlation between in vivo tropism and in vitro conversion efficiency was obtained, which suggested that the mechanisms involved are common to various prion strains. A significant correlation was maintained when the relative amplification values were corrected for the PrPc relative level of each substrate, which suggests the involvement of region-specific cofactors different from PrPc. This was confirmed by showing that tissue preparations from mice devoid of PrPc could modulate PMCA efficacy in a tissue-specific manner [46]. 
Substrates:

- Subject without CJD or neurodegenerative disease

- Known genotype at codon 129 of PRNP

- Short post-mortem delay

-5 regions of interest

Seed:

- Subject with CJD

- Frontal isocortex

- Known genotype at codon 129 of PRNP

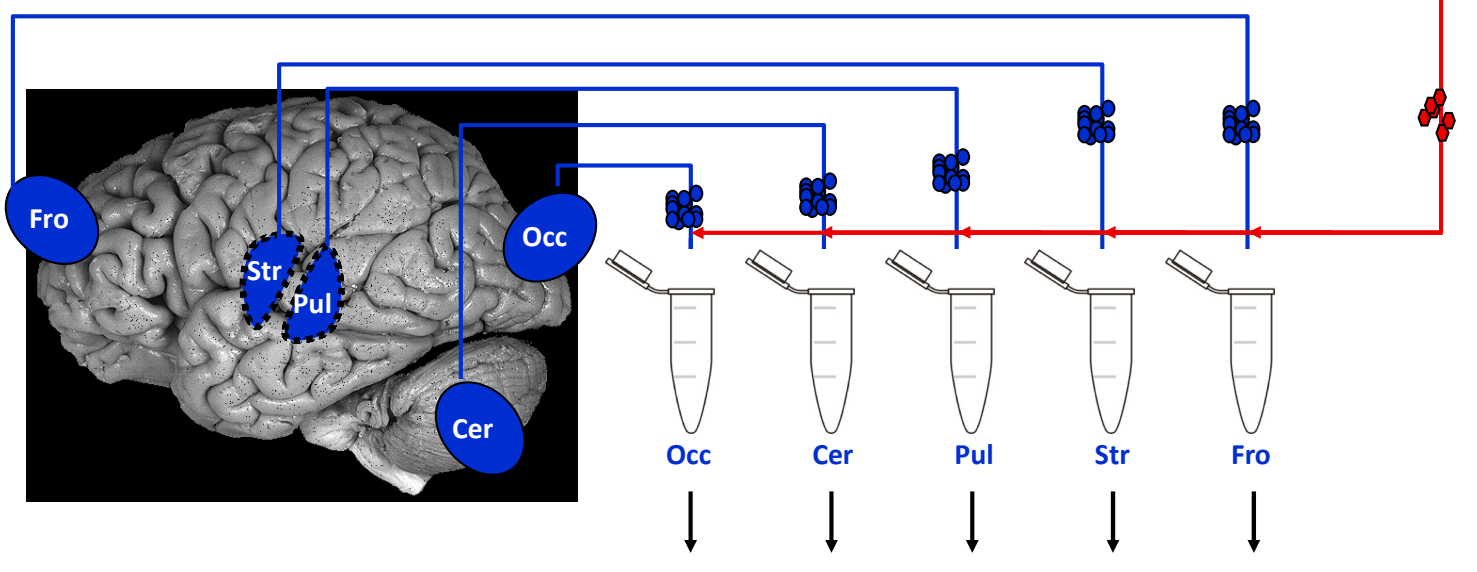

PMCA: 1 Round

Scheme 2. Modeling of region-specific targeting observed in Creutzfeldt-Jakob disease rsPMCA setup is based on standard PMCA parameters (one round only). It uses, as substrates, key brain regions that are known to be differentially affected by PrPsc deposition in various human prion disorders and scrapie experimental models. In humans, tissues were selected on the basis of the availability of autopsy-obtained frozen brain material. In this illustration, a set of five cerebral regions is used to prepare PMCA substrates: frontal isocortex (Fro), occipital isocortex (Occ), striatum (Str), pulvinar (Pul), and cerebellar cortex (Cer). CJD: Creutzfeldt-Jakob Disease.

In contrast with our results, the PrPsc in vitro conversion efficiency did not match the pattern of deposition observed in a hamster scrapie model [74]. The discrepancy between the two studies may be simply explained by the use of distinct prion strains in different species. It is worth noting that the effect of PMCA cofactors may vary with species. Deleault et al. [69] reported that, whereas hamster PrPsc preferentially utilizes RNAs as a cofactor, RNAs fail to facilitate mouse PrPsc amplification. In addition, a clarification step of the substrates using centrifugation was performed in the hamster study by $\mathrm{Hu}$ and collaborators [74] and may have removed some of the components responsible for region-specific modulation of PMCA. It was suggested that in vitro conversion using a hamster substrate was mostly dependent on the availability of PrPc. However, it was not confirmed in a study using grey and white matter of the same sample [75]. Moreover, it was shown that a high level of PrPc expression does not systematically correlate with a high conversion rate. Cell-free in vitro conversion activity assay using brains from PrP overexpressing mice as substrate does not show a proportional increase in conversion activity as compared with wild-type mice [76]. Our data obtained using PMCA suggest that additional molecular factors, distinct from PrPc, are involved in the regional brain targeting by human prion strains. Our conclusion is supported by in vitro results showing that $\mathrm{PrP}$ expression is not the limiting factor between highly and poorly susceptible N2a cells [77].

The glycosylation of PrPc is known to interact with prion propagation [78]. Moreover, the glycoform ratio of PrPres may vary between brain structures in CJD [79]. A study has demonstrated that brain targeting following peripheral inoculation of two TSE strains in transgenic mice expressing different glycosylated forms of PrP was profoundly influenced by the glycosylation status of host 
$\operatorname{PrP}$ [80]. Intracerebral inoculation of three TSE strains in mice, carrying mutations at the first, second, or both PrP N-linked glycosylation site, suggests that alterations in PrP glycosylation modulate the incubation period, and that glycosylation at the first site may have an effect on strain targeting [81]. In our work, the glycosylation status of PrPc did not appear to be an important region-specific cofactor since we did not observe any significant difference in the distribution of PrPc glycoforms, according to the human brain regions used as PMCA substrates and showing various efficiencies in PrP conversion [46].

Among the non-PrP molecular factors relevant in PMCA, ribonucleic acids are potential candidates $[59,62,65]$. A study with murine strains showed that RNAs are catalysts of the strain-specific conversion [82]. The use of murine and hamster substrates depleted in RNA altered the rate of strain adaptation [83]. In our hands, the digestion of vCJD seeds and tgMet brain substrates with RNAse A, T1, V1, and S7 nuclease or benzonase prior to rsPMCA did not alter the amplification differences between the brain regions used as substrates. This suggests that RNAs are not essential cofactors that influence brain targeting by human prion strains. Other cofactor candidates include metal ions [64], glycosaminoglycans [84], laminin receptor (LRP/LR) [85-87], and anionic lipids [61,75]. For example, poly-anionic cofactors affected the strain specificity of infectious recombinant prions generated in vitro [88]. Another group has reported the faithful and stable replication in vitro of a hamster strain using also recombinant $\operatorname{PrP}$ as a substrate, and a mixture of phospho-lipoproteins and synthetic nucleic acid polyA [89]. It is worth noting that a possible cause of divergence between the classifications of SCJD proposed by Collinge and Parchi may be related to the presence of metal ions such as copper and zinc [90], which would affect PrPsc conformation.

\section{Combining Cellular with Acellular Models}

Thus, the use of PMCA allows to selectively investigate the role of different substrates. Most of them originate from experimental models that overexpress PrPc. When available, human substrates are valuable. However, the amplification efficiency is affected in our hands by the post mortem delay. Some research teams have attempted to develop more simple substrates. The use of fractions containing lipid rafts where PrPc content is enriched and isolated from hamster brain homogenates as substrates has been helpful to study the components (including cofactors) involved in PMCA reaction [68,91]. Others have used purified PrPc from the brain [59], from cultured cells [92], platelet lysates [66], or recombinant PrP expressed in bacterial cells as substrates [61,93], and have proposed minimal components that are necessary to produce de novo infectious prions with PMCA. Using, for the first time, lysates of cultured mammalian cells as substrates, Mays and collaborators showed that in vitro amplification of mouse-adapted and hamster-adapted strains is possible [94]. This was an important step because cell culture lysates were considered until they were unable to support PrP conversion in PMCA alone [95]. However, they had been previously used in a cell free assay to investigate the role of polyanions in the process of PrPsc formation [76]. Furthermore, Yokoyama and collaborators showed that vCJD prions could be amplified using human cell lysates (293F cell line) supplemented with heparin as substrate, and that the effect of heparin on cell-PMCA was strain dependent [96].

The perspective of using cell lysates with PMCA is promising because these substrates are much less expensive than brain material from animal models, which is easily available and more ethical. We confirmed that cell lysates could be used as PMCA substrates using N2a cells (data not shown). The next step is to set up a neuron-specific PMCA based on primary cultures of neurons from various brain structures such as the mouse cortex, the striatum, and the cerebellum as substrates to study the strain-targeting phenomenon (Scheme 3). 

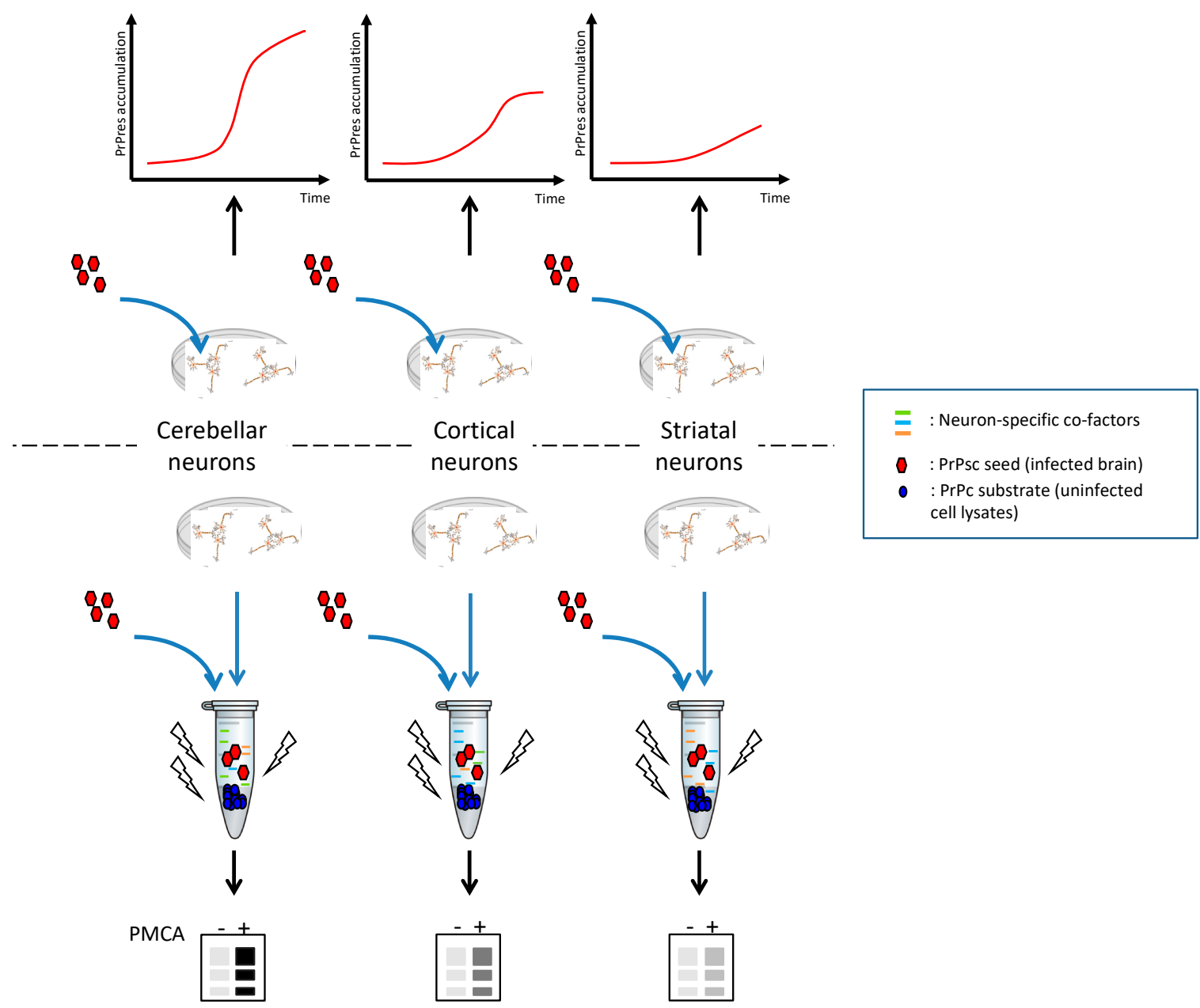

Scheme 3. Schematic representation of cellular neuron-specific tropism and general principle of neuron-specific PMCA (nsPMCA). Infection kinetics are compared with amplification levels. Manipulation of neuronal cultures (change of protein expression, post-translational modifications, inhibition of specific pathways) before nsPMCA will help identify neuron-specific molecular co-factors. PMCA -: no PMCA was applied. PMCA +: one round of PMCA was applied. The figures are purely illustrative and do not present experimental data.

Although a statistical difference was detected only between 22L and ME7 strains, using CGN lysates from C57BL/ 6 mice as substrates for nsPMCA, our preliminary data suggest that amplification is faster with 22L, intermediate with 139A, and slower with ME7 strains (Figure 1). The kinetics of infection in CGN follows the same order, i.e., 22L is the first strain to reach its steady state of PrPres accumulation, while 139A was the second and ME7 was the third strain to reach a plateau [31]. Moreover, when considering previous in vivo results, the incubation period in C57BL/6 mice inoculated in the cerebellum region with these three strains was the shortest with 22L, intermediate with 139A, and the longest with ME7 [21]. 


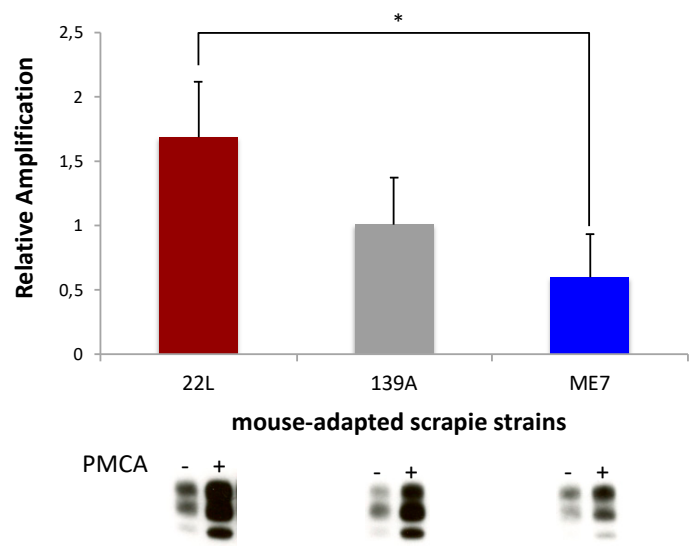

Figure 1. Neuronal strain tropism using in vitro models. Relative amplifications obtained with mouse-adapted scrapie strains (139A, 22L and ME7) using CGN lysates from C57BL/6 mice. PMCA-, no PMCA was applied. PMCA+, one round of PMCA was applied. Neuron-specific PMCA results are representative of four independent experiments performed in duplicates. Values for the three PrPres glycoforms were measured on blots with a non-saturated signal using a GS-800 calibrated densitometer and Quantity One software (Bio-Rad Laboratories). Relative amplification = [(PMCA+) - (PMCA-)]/(PMCA-) was calculated as a function of the value of the internal standard of amplification included in each experiment. For statistical comparisons between strains, the nonparametric Mann-Whitney test was used. Analyses were performed using SigmaStat (ver 3.5, Available online: https:/ / systatsoftware.com). Data are presented as the mean $+/-$ SEM. ${ }^{*} p<0.05$ was considered to be statistically significant.

Our preliminary results suggest that primary neurons can be used as a substrate to explore prion tropism in acellular models. Our primary neuronal cultures are devoid of microglial cells. It has been shown, however, that microglia contribute to amyloid formation and enhance neuronal destruction in prion diseases [97]. On the other hand, the extensive microglial activation accompanying prion diseases represents an efficient defensive reaction [98]. Our combined approach also allows the study of the role of glial cell-associated molecular factors in PrPc conversion by modifying the ratio of microglial cells and astrocytes in co-cultures, and by adding conditioned medium from prion exposed microglia to neuronal cultures. In addition, manipulating cell components in neuronal cultures from various brain areas (using selectively lipases, proteases, etc.) will help us identify potential cofactors. As a complementary approach, the use of antibodies or competitors and the manipulation of gene expression should allow us to target most known PrPc partners [99]. These strategies may be completed by PrP interactome studies that should take into account possible variations between different neuronal cultures. In the hypothesis that cofactors would be revealed in these cellular or acellular systems, $\mathrm{KO}$ models for these newly identified molecules will be helpful to validate their role in modulating the prion-strain tropism.

\section{Conclusions}

Deciphering the mechanisms involved in the strain tropism phenomenon requires new approaches relying on in vitro models of prion replication. Recent evidence from experiments using primary infected cultures supports that a strain-specific tropism for different types of neuronal populations may contribute to the differential targeting of brain areas. This phenomenon may be complementary to the role of intercellular connectivity in the spread of misfolded prion protein aggregates. Region-specific PMCA suggests that such a neuronal tropism involves molecular factors in addition to the potential role of cell functions and cell-to-cell interactions that may differ between cells from various brain areas. These results underline the value of a regional in vitro study of prion propagation that could be refined by the use of co-cultures of neuronal and non-neuronal cells. The combination of these approaches should make possible the identification of inhibiting or enhancing local cofactors of prion 
conversion that are involved in strain tropism. Beyond the prion field, these new methods may also help us understand the selectivity of brain lesions in non-prion neurodegenerative diseases, in which a protein-specific pattern of lesion dissemination and the occurrence of prion-like mechanisms of propagation have been shown [84].

Author Contributions: All authors contributed to the writing, editing, and contents of this manuscript.

Funding: Santé Publique France and by the program "Investissement avenir" ANR-10-IAIHU-06 supported this work.

Conflicts of Interest: Stéphane Haïk has received research support from MedDay Pharmaceuticals, LFB Biomedicaments and Institut de Recherche Servier.

\section{References}

1. Prusiner, S.B. Prions. Proc. Natl. Acad. Sci. USA 1998, 95, 13363-13383. [CrossRef] [PubMed]

2. Parchi, P.; Zou, W.; Wang, W.; Brown, P.; Capellari, S.; Ghetti, B.; Kopp, N.; Schulz-Schaeffer, W.J; Kretzschmar, H.A.; Head, M.W.; et al. Genetic influence on the structural variations of the abnormal prion protein. Proc. Natl. Acad. Sci. USA 2000, 97, 10168-10172. [CrossRef] [PubMed]

3. Parchi, P.; Castellani, R.; Capellari, S.; Ghetti, B.; Young, K.; Chen, S.G.; Farlow, M.; Dickson, D.W.; Sima, A.A.; Trojanowski, J.Q.; et al. Molecular basis of phenotypic variability in sporadic creutzfeldt-jakob disease. Ann. Neurol. 1996, 39, 767-778. [CrossRef] [PubMed]

4. Parchi, P.; Giese, A.; Capellari, S.; Brown, P.; Schulz-Schaeffer, W.; Windl, O.; Zerr, I.; Budka, H.; Kopp, N.; Piccardo, P.; et al. Classification of sporadic creutzfeldt-jakob disease based on molecular and phenotypic analysis of 300 subjects. Ann. Neurol. 1999, 46, 224-233. [CrossRef]

5. Parchi, P.; Notari, S.; Weber, P.; Schimmel, H.; Budka, H.; Ferrer, I.; Haik, S.; Hauw, J.J.; Head, M.W.; Ironside, J.W.; et al. Inter-laboratory assessment of prpsc typing in creutzfeldt-jakob disease: A western blot study within the neuroprion consortium. Brain Pathol. 2009, 19, 384-391. [CrossRef] [PubMed]

6. Hill, A.F.; Joiner, S.; Wadsworth, J.D.; Sidle, K.C.; Bell, J.E.; Budka, H.; Ironside, J.W.; Collinge, J. Molecular classification of sporadic creutzfeldt-jakob disease. Brain 2003, 126, 1333-1346. [CrossRef] [PubMed]

7. Rudge, P.; Jaunmuktane, Z.; Adlard, P.; Bjurstrom, N.; Caine, D.; Lowe, J.; Norsworthy, P.; Hummerich, H.; Druyeh, R.; Wadsworth, J.D.; et al. Iatrogenic cjd due to pituitary-derived growth hormone with genetically determined incubation times of up to 40 years. Brain 2015, 138, 3386-3399. [CrossRef]

8. Parchi, P.; de Boni, L.; Saverioni, D.; Cohen, M.L.; Ferrer, I.; Gambetti, P.; Gelpi, E.; Giaccone, G.; Hauw, J.J.; Hoftberger, R.; et al. Consensus classification of human prion disease histotypes allows reliable identification of molecular subtypes: An inter-rater study among surveillance centres in europe and USA. Acta Neuropathol. 2012, 124, 517-529. [CrossRef] [PubMed]

9. Aguzzi, A. Staining, straining and restraining prions. Nat. Neurosci. 2008, 11, 1239-1240. [CrossRef]

10. Pattison, I.H.; Millson, G.C. Scrapie produced experimentally in goats with special reference to the clinical syndrome. J. Comp. Pathol. Ther. 1961, 71, 101-108. [CrossRef]

11. Bruce, M.E. Scrapie strain variation and mutation. Br. Med. Bull. 1993, 49, 822-838. [CrossRef] [PubMed]

12. Bruce, M.E.; Will, R.G.; Ironside, J.W.; McConnell, I.; Drummond, D.; Suttie, A.; McCardle, L.; Chree, A.; Hope, J.; Birkett, C.; et al. Transmissions to mice indicate that 'new variant' cjd is caused by the bse agent. Nature 1997, 389, 498-501. [CrossRef] [PubMed]

13. Casalone, C.; Zanusso, G.; Acutis, P.; Ferrari, S.; Capucci, L.; Tagliavini, F.; Monaco, S.; Caramelli, M. Identification of a second bovine amyloidotic spongiform encephalopathy: Molecular similarities with sporadic creutzfeldt-jakob disease. Proc. Natl. Acad. Sci. USA 2004, 101, 3065-3070. [CrossRef] [PubMed]

14. Biacabe, A.G.; Laplanche, J.L.; Ryder, S.; Baron, T. Distinct molecular phenotypes in bovine prion diseases. EMBO Rep. 2004, 5, 110-115. [CrossRef] [PubMed]

15. Williams, E.S.; Young, S. Chronic wasting disease of captive mule deer: A spongiform encephalopathy. J. Wildl. Dis. 1980, 16, 89-98. [CrossRef] [PubMed]

16. Benestad, S.L.; Telling, G.C. Chronic wasting disease: An evolving prion disease of cervids. Handb. Clin. Neurol. 2018, 153, 135-151. [PubMed]

17. Bishop, M.T.; Will, R.G.; Manson, J.C. Defining sporadic creutzfeldt-jakob disease strains and their transmission properties. Proc. Natl. Acad. Sci. USA 2010, 107, 12005-12010. [CrossRef] 
18. Diack, A.B.; Ritchie, D.; Bishop, M.; Pinion, V.; Brandel, J.P.; Haik, S.; Tagliavini, F.; Van Duijn, C.; Belay, E.D.; Gambetti, P.; et al. Constant transmission properties of variant creutzfeldt-jakob disease in 5 countries. Emerg. Infect. Dis. 2012, 18, 1574-1579. [CrossRef]

19. Haik, S.; Brandel, J.P. Biochemical and strain properties of cjd prions: Complexity versus simplicity. J. Neurochem. 2011, 119, 251-261. [CrossRef]

20. Bruce, M.E. Serial studies on the development of cerebral amyloidosis and vacuolar degeneration in murine scrapie. J. Comp. Pathol. Ther. 1981, 91, 589-597. [CrossRef]

21. Kim, Y.S.; Carp, R.L.; Callahan, S.M.; Wisniewski, H.M. Incubation periods and survival times for mice injected stereotaxically with three scrapie strains in different brain regions. J. Gen. Virol. 1987, 68, 695-702. [CrossRef] [PubMed]

22. Parchi, P.; Cescatti, M.; Notari, S.; Schulz-Schaeffer, W.J.; Capellari, S.; Giese, A.; Zou, W.Q.; Kretzschmar, H.; Ghetti, B.; Brown, P. Agent strain variation in human prion disease: Insights from a molecular and pathological review of the national institutes of health series of experimentally transmitted disease. Brain 2010, 133, 3030-3042. [CrossRef] [PubMed]

23. Haik, S.; Brandel, J.P. Infectious prion diseases in humans: Cannibalism, iatrogenicity and zoonoses. Infect. Genet. Evol. 2014, 26, 303-312. [CrossRef] [PubMed]

24. Brandel, J.P.; Heath, C.A.; Head, M.W.; Levavasseur, E.; Knight, R.; Laplanche, J.L.; Langeveld, J.P.; Ironside, J.W.; Hauw, J.J.; Mackenzie, J.; et al. Variant creutzfeldt-jakob disease in france and the united kingdom: Evidence for the same agent strain. Ann. Neurol. 2009, 65, 249-256. [CrossRef] [PubMed]

25. Ayers, J.I.; Kincaid, A.E.; Bartz, J.C. Prion strain targeting independent of strain-specific neuronal tropism. J. Virol. 2009, 83, 81-87. [CrossRef] [PubMed]

26. Ryou, C.; Mays, C.E. Prion propagation in vitro: Are we there yet? Int. J. Med. Sci. 2008, 5, 347-353. [CrossRef] [PubMed]

27. Klohn, P.C.; Stoltze, L.; Flechsig, E.; Enari, M.; Weissmann, C. A quantitative, highly sensitive cell-based infectivity assay for mouse scrapie prions. Proc. Natl. Acad. Sci. USA 2003, 100, 11666-11671. [CrossRef]

28. Cronier, S.; Laude, H.; Peyrin, J.M. Prions can infect primary cultured neurons and astrocytes and promote neuronal cell death. Proc. Natl. Acad. Sci. USA 2004, 101, 12271-12276. [CrossRef]

29. Cronier, S.; Beringue, V.; Bellon, A.; Peyrin, J.M.; Laude, H. Prion strain- and species-dependent effects of antiprion molecules in primary neuronal cultures. J. Virol. 2007, 81, 13794-13800. [CrossRef]

30. Falsig, J.; Sonati, T.; Herrmann, U.S.; Saban, D.; Li, B.; Arroyo, K.; Ballmer, B.; Liberski, P.P.; Aguzzi, A. Prion pathogenesis is faithfully reproduced in cerebellar organotypic slice cultures. PLoS Pathog. 2012, 8, e1002985. [CrossRef]

31. Hannaoui, S.; Maatouk, L.; Privat, N.; Levavasseur, E.; Faucheux, B.A.; Haik, S. Prion propagation and toxicity occur in vitro with two-phase kinetics specific to strain and neuronal type. J. Virol. 2013, 87, 2535-2548. [CrossRef] [PubMed]

32. Sandberg, M.K.; Al-Doujaily, H.; Sharps, B.; Clarke, A.R.; Collinge, J. Prion propagation and toxicity in vivo occur in two distinct mechanistic phases. Nature 2011, 470, 540-542. [CrossRef] [PubMed]

33. Hannaoui, S.; Gougerot, A.; Privat, N.; Levavasseur, E.; Bizat, N.; Hauw, J.J.; Brandel, J.P.; Haik, S. Cycline efficacy on the propagation of human prions in primary cultured neurons is strain-specific. J. Infect. Dis. 2014, 209, 1144-1148. [CrossRef] [PubMed]

34. Krejciova, Z.; Alibhai, J.; Zhao, C.; Krencik, R.; Rzechorzek, N.M.; Ullian, E.M.; Manson, J.; Ironside, J.W.; Head, M.W.; Chandran, S. Human stem cell-derived astrocytes replicate human prions in a prnp genotype-dependent manner. J. Exp. Med. 2017, 214, 3481-3495. [CrossRef] [PubMed]

35. Liddelow, S.; Barres, B. Snapshot: Astrocytes in health and disease. Cell 2015, 162, 1170. [CrossRef] [PubMed]

36. Liddelow, S.A.; Guttenplan, K.A.; Clarke, L.E.; Bennett, F.C.; Bohlen, C.J.; Schirmer, L.; Bennett, M.L.; Munch, A.E.; Chung, W.S.; Peterson, T.C.; et al. Neurotoxic reactive astrocytes are induced by activated microglia. Nature 2017, 541, 481-487. [CrossRef] [PubMed]

37. Kocisko, D.A.; Come, J.H.; Priola, S.A.; Chesebro, B.; Raymond, G.J.; Lansbury, P.T.; Caughey, B. Cell-free formation of protease-resistant prion protein. Nature 1994, 370, 471-474. [CrossRef]

38. Saborio, G.P.; Permanne, B.; Soto, C. Sensitive detection of pathological prion protein by cyclic amplification of protein misfolding. Nature 2001, 411, 810-813. [CrossRef]

39. Castilla, J.; Saa, P.; Hetz, C.; Soto, C. In vitro generation of infectious scrapie prions. Cell 2005, 121, $195-206$. [CrossRef] 
40. Castilla, J.; Saa, P.; Morales, R.; Abid, K.; Maundrell, K.; Soto, C. Protein misfolding cyclic amplification for diagnosis and prion propagation studies. Methods Enzymol. 2006, 412, 3-21.

41. Klingeborn, M.; Race, B.; Meade-White, K.D.; Chesebro, B. Lower specific infectivity of protease-resistant prion protein generated in cell-free reactions. Proc. Natl. Acad. Sci. USA 2011, 108, E1244-E1253. [CrossRef] [PubMed]

42. Weber, P.; Giese, A.; Piening, N.; Mitteregger, G.; Thomzig, A.; Beekes, M.; Kretzschmar, H.A. Cell-free formation of misfolded prion protein with authentic prion infectivity. Proc. Natl. Acad. Sci. USA 2006, 103, 15818-15823. [CrossRef] [PubMed]

43. Saa, P.; Castilla, J.; Soto, C. Ultra-efficient replication of infectious prions by automated protein misfolding cyclic amplification. J. Biol. Chem. 2006, 281, 35245-35252. [CrossRef] [PubMed]

44. Jones, M.; Peden, A.H.; Prowse, C.V.; Groner, A.; Manson, J.C.; Turner, M.L.; Ironside, J.W.; MacGregor, I.R.; Head, M.W. In vitro amplification and detection of variant creutzfeldt-jakob disease prpsc. J. Pathol. 2007, 213, 21-26. [CrossRef] [PubMed]

45. Jones, M.; Peden, A.H.; Wight, D.; Prowse, C.; Macgregor, I.; Manson, J.; Turner, M.; Ironside, J.W.; Head, M.W. Effects of human prpsc type and prnp genotype in an in-vitro conversion assay. Neuroreport 2008, 19, 1783-1786. [CrossRef]

46. Privat, N.; Levavasseur, E.; Yildirim, S.; Hannaoui, S.; Brandel, J.P.; Laplanche, J.L.; Beringue, V.; Seilhean, D.; Haik, S. Region-specific protein misfolding cyclic amplification reproduces brain tropism of prion strains. J. Biol. Chem. 2017, 292, 16688-16696. [CrossRef]

47. Castilla, J.; Gonzalez-Romero, D.; Saa, P.; Morales, R.; De Castro, J.; Soto, C. Crossing the species barrier by $\operatorname{prp}(\mathrm{sc})$ replication in vitro generates unique infectious prions. Cell 2008, 134, 757-768. [CrossRef]

48. Green, K.M.; Castilla, J.; Seward, T.S.; Napier, D.L.; Jewell, J.E.; Soto, C.; Telling, G.C. Accelerated high fidelity prion amplification within and across prion species barriers. PLoS Pathog. 2008, 4, e1000139. [CrossRef]

49. Fernandez-Borges, N.; de Castro, J.; Castilla, J. In vitro studies of the transmission barrier. Prion 2009, 3, 220-223. [CrossRef]

50. Jones, M.; Wight, D.; Barron, R.; Jeffrey, M.; Manson, J.; Prowse, C.; Ironside, J.W.; Head, M.W. Molecular model of prion transmission to humans. Emerg. Infect. Dis. 2009, 15, 2013-2016. [CrossRef]

51. Jones, M.; Peden, A.H.; Head, M.W.; Ironside, J.W. The application of in vitro cell-free conversion systems to human prion diseases. Acta Neuropathol. 2010, 121, 135-143. [CrossRef] [PubMed]

52. Beck, K.E.; Thorne, L.; Lockey, R.; Vickery, C.M.; Terry, L.A.; Bujdoso, R.; Spiropoulos, J. Strain typing of classical scrapie by transgenic mouse bioassay using protein misfolding cyclic amplification to replace primary passage. PLOS ONE 2013, 8, e57851. [CrossRef] [PubMed]

53. Castilla, J.; Saa, P.; Soto, C. Detection of prions in blood. Nat. Med. 2005, 11, 982-985. [CrossRef] [PubMed]

54. Saa, P.; Castilla, J.; Soto, C. Presymptomatic detection of prions in blood. Science 2006, 313, 92-94. [CrossRef] [PubMed]

55. Murayama, Y.; Yoshioka, M.; Okada, H.; Takata, M.; Yokoyama, T.; Mohri, S. Urinary excretion and blood level of prions in scrapie-infected hamsters. J. Gen. Virol. 2007, 88, 2890-2898. [CrossRef] [PubMed]

56. Gonzalez-Romero, D.; Barria, M.A.; Leon, P.; Morales, R.; Soto, C. Detection of infectious prions in urine. FEBS Lett. 2008, 582, 3161-3166. [CrossRef] [PubMed]

57. Haley, N.J.; Seelig, D.M.; Zabel, M.D.; Telling, G.C.; Hoover, E.A. Detection of cwd prions in urine and saliva of deer by transgenic mouse bioassay. PLOS ONE 2009, 4, e4848. [CrossRef]

58. Tattum, M.H.; Jones, S.; Pal, S.; Collinge, J.; Jackson, G.S. Discrimination between prion-infected and normal blood samples by protein misfolding cyclic amplification. Transfusion 2010, 50, 996-1002. [CrossRef]

59. Deleault, N.R.; Harris, B.T.; Rees, J.R.; Supattapone, S. Formation of native prions from minimal components in vitro. Proc. Natl. Acad. Sci. USA 2007, 104, 9741-9746. [CrossRef]

60. Barria, M.A.; Mukherjee, A.; Gonzalez-Romero, D.; Morales, R.; Soto, C. De novo generation of infectious prions in vitro produces a new disease phenotype. PLoS Pathog. 2009, 5, e1000421. [CrossRef]

61. Wang, F.; Wang, X.; Yuan, C.G.; Ma, J. Generating a prion with bacterially expressed recombinant prion protein. Science 2010, 327, 1132-1135. [CrossRef] [PubMed]

62. Deleault, N.R.; Lucassen, R.W.; Supattapone, S. Rna molecules stimulate prion protein conversion. Nature 2003, 425, 717-720. [CrossRef] 
63. Nishina, K.A.; Deleault, N.R.; Mahal, S.P.; Baskakov, I.; Luhrs, T.; Riek, R.; Supattapone, S. The stoichiometry of host prpc glycoforms modulates the efficiency of prpsc formation in vitro. Biochemistry 2006, 45, 14129-14139. [CrossRef] [PubMed]

64. Orem, N.R.; Geoghegan, J.C.; Deleault, N.R.; Kascsak, R.; Supattapone, S. Copper (ii) ions potently inhibit purified prpres amplification. J. Neurochem. 2006, 96, 1409-1415. [CrossRef] [PubMed]

65. Geoghegan, J.C.; Valdes, P.A.; Orem, N.R.; Deleault, N.R.; Williamson, R.A.; Harris, B.T.; Supattapone, S. Selective incorporation of polyanionic molecules into hamster prions. J. Biol. Chem. 2007, 282, 36341-36353. [CrossRef] [PubMed]

66. Jones, M.; Peden, A.H.; Yull, H.; Wight, D.; Bishop, M.T.; Prowse, C.V.; Turner, M.L.; Ironside, J.W.; MacGregor, I.R.; Head, M.W. Human platelets as a substrate source for the in vitro amplification of the abnormal prion protein (prp) associated with variant creutzfeldt-jakob disease. Transfusion 2009, 49, 376-384. [CrossRef] [PubMed]

67. Mays, C.E.; Titlow, W.; Seward, T.; Telling, G.C.; Ryou, C. Enhancement of protein misfolding cyclic amplification by using concentrated cellular prion protein source. Biochem. Biophys. Res. Commun. 2009, 388, 306-310. [CrossRef]

68. Abid, K.; Morales, R.; Soto, C. Cellular factors implicated in prion replication. FEBS Lett. 2010, 584, $2409-2414$. [CrossRef] [PubMed]

69. Deleault, N.R.; Kascsak, R.; Geoghegan, J.C.; Supattapone, S. Species-dependent differences in cofactor utilization for formation of the protease-resistant prion protein in vitro. Biochemistry 2010, 49, 3928-3934. [CrossRef] [PubMed]

70. Gonzalez-Montalban, N.; Makarava, N.; Ostapchenko, V.G.; Savtchenk, R.; Alexeeva, I.; Rohwer, R.G.; Baskakov, I.V. Highly efficient protein misfolding cyclic amplification. PLoS Pathog. 2011, 7, e1001277. [CrossRef] [PubMed]

71. Mays, C.E.; Ryou, C. Plasminogen stimulates propagation of protease-resistant prion protein in vitro. FASEB J. 2010, 24, 5102-5112. [CrossRef] [PubMed]

72. Mays, C.E.; Ryou, C. Plasminogen: A cellular protein cofactor for prpsc propagation. Prion 2011, 5, $22-27$. [CrossRef] [PubMed]

73. Piro, J.R.; Harris, B.T.; Supattapone, S. In situ photodegradation of incorporated polyanion does not alter prion infectivity. PLoS Pathog. 2011, 7, e1002001. [CrossRef] [PubMed]

74. Hu, P.P.; Morales, R.; Duran-Aniotz, C.; Moreno-Gonzalez, I.; Khan, U.; Soto, C. Role of prion replication in the strain-dependent brain regional distribution of prions. J. Biol. Chem. 2016, 291, 12880-12887. [CrossRef] [PubMed]

75. Klemm, H.M.; Welton, J.M.; Masters, C.L.; Klug, G.M.; Boyd, A.; Hill, A.F.; Collins, S.J.; Lawson, V.A. The prion protein preference of sporadic creutzfeldt-jakob disease subtypes. J. Biol. Chem. 2012, 287, 36465-36472. [CrossRef] [PubMed]

76. Lawson, V.A.; Lumicisi, B.; Welton, J.; Machalek, D.; Gouramanis, K.; Klemm, H.M.; Stewart, J.D.; Masters, C.L.; Hoke, D.E.; Collins, S.J.; et al. Glycosaminoglycan sulphation affects the seeded misfolding of a mutant prion protein. PLoS ONE 2010, 5, e12351. [CrossRef] [PubMed]

77. Enari, M.; Flechsig, E.; Weissmann, C. Scrapie prion protein accumulation by scrapie-infected neuroblastoma cells abrogated by exposure to a prion protein antibody. Proc. Natl. Acad. Sci. USA 2001, 98, 9295-9299. [CrossRef]

78. Priola, S.A.; Lawson, V.A. Glycosylation influences cross-species formation of protease-resistant prion protein. EMBO J. 2001, 20, 6692-6699. [CrossRef]

79. Levavasseur, E.; Laffont-Proust, I.; Morain, E.; Faucheux, B.A.; Privat, N.; Peoc'h, K.; Sazdovitch, V.; Brandel, J.P.; Hauw, J.J.; Haik, S. Regulating factors of prp glycosylation in creutzfeldt-jakob disease-Implications for the dissemination and the diagnosis of human prion strains. PLoS ONE 2008, 3, e2786. [CrossRef]

80. Cancellotti, E.; Bradford, B.M.; Tuzi, N.L.; Hickey, R.D.; Brown, D.; Brown, K.L.; Barron, R.M.; Kisielewski, D.; Piccardo, P.; Manson, J.C. Glycosylation of prpc determines timing of neuroinvasion and targeting in the brain following transmissible spongiform encephalopathy infection by a peripheral route. J. Virol. 2010, 84, 3464-3475. [CrossRef] 
81. Tuzi, N.L.; Cancellotti, E.; Baybutt, H.; Blackford, L.; Bradford, B.; Plinston, C.; Coghill, A.; Hart, P.; Piccardo, P.; Barron, R.M.; et al. Host prp glycosylation: A major factor determining the outcome of prion infection. PLoS Biol. 2008, 6, e100. [CrossRef] [PubMed]

82. Saa, P.; Sferrazza, G.F.; Ottenberg, G.; Oelschlegel, A.M.; Dorsey, K.; Lasmezas, C.I. Strain-specific role of rnas in prion replication. J. Virol. 2012, 86, 10494-10504. [CrossRef] [PubMed]

83. Katorcha, E.; Gonzalez-Montalban, N.; Makarava, N.; Kovacs, G.G.; Baskakov, I.V. Prion replication environment defines the fate of prion strain adaptation. PLoS Pathog. 2018, 14, e1007093. [CrossRef] [PubMed]

84. Snow, A.D.; Wight, T.N.; Nochlin, D.; Koike, Y.; Kimata, K.; DeArmond, S.J.; Prusiner, S.B. Immunolocalization of heparan sulfate proteoglycans to the prion protein amyloid plaques of gerstmann-straussler syndrome, creutzfeldt-jakob disease and scrapie. Lab. Investig. 1990, 63, 601-611. [PubMed]

85. Rieger, R.; Edenhofer, F.; Lasmezas, C.I.; Weiss, S. The human 37-kda laminin receptor precursor interacts with the prion protein in eukaryotic cells. Nat. Med. 1997, 3, 1383-1388. [CrossRef] [PubMed]

86. Gauczynski, S.; Peyrin, J.M.; Haik, S.; Leucht, C.; Hundt, C.; Rieger, R.; Krasemann, S.; Deslys, J.P.; Dormont, D.; Lasmezas, C.I.; et al. The 37-kda/67-kda laminin receptor acts as the cell-surface receptor for the cellular prion protein. EMBO J. 2001, 20, 5863-5875. [CrossRef] [PubMed]

87. Hundt, C.; Peyrin, J.M.; Haik, S.; Gauczynski, S.; Leucht, C.; Rieger, R.; Riley, M.L.; Deslys, J.P.; Dormont, D.; Lasmezas, C.I.; et al. Identification of interaction domains of the prion protein with its 37-kda/67-kda laminin receptor. EMBO J. 2001, 20, 5876-5886. [CrossRef]

88. Fernandez-Borges, N.; Di Bari, M.A.; Erana, H.; Sanchez-Martin, M.; Pirisinu, L.; Parra, B.; Elezgarai, S.R.; Vanni, I.; Lopez-Moreno, R.; Vaccari, G.; et al. Cofactors influence the biological properties of infectious recombinant prions. Acta Neuropathol. 2018, 135, 179-199. [CrossRef]

89. Makarava, N.; Savtchenko, R.; Lasch, P.; Beekes, M.; Baskakov, I.V. Preserving prion strain identity upon replication of prions in vitro using recombinant prion protein. Acta Neuropathol. Commun. 2018, 6, 92. [CrossRef]

90. Wadsworth, J.D.; Hill, A.F.; Joiner, S.; Jackson, G.S.; Clarke, A.R.; Collinge, J. Strain-specific prion-protein conformation determined by metal ions. Nat. Cell Biol. 1999, 1, 55-59. [CrossRef]

91. Nishina, K.; Deleault, N.R.; Lucassen, R.W.; Supattapone, S. In vitro prion protein conversion in detergent-solubilized membranes. Biochemistry 2004, 43, 2613-2621. [CrossRef] [PubMed]

92. Geoghegan, J.C.; Miller, M.B.; Kwak, A.H.; Harris, B.T.; Supattapone, S. Trans-dominant inhibition of prion propagation in vitro is not mediated by an accessory cofactor. PLoS Pathog. 2009, 5, e1000535. [CrossRef]

93. Kim, J.I.; Cali, I.; Surewicz, K.; Kong, Q.; Raymond, G.J.; Atarashi, R.; Race, B.; Qing, L.; Gambetti, P.; Caughey, B.; et al. Mammalian prions generated from bacterially expressed prion protein in the absence of any mammalian cofactors. J. Biol. Chem. 2010, 285, 14083-14087. [CrossRef]

94. Mays, C.E.; Yeom, J.; Kang, H.E.; Bian, J.; Khaychuk, V.; Kim, Y.; Bartz, J.C.; Telling, G.C.; Ryou, C. In vitro amplification of misfolded prion protein using lysate of cultured cells. PLoS ONE 2011, 6, e18047. [CrossRef] [PubMed]

95. Saborio, G.P.; Soto, C.; Kascsak, R.J.; Levy, E.; Kascsak, R.; Harris, D.A.; Frangione, B. Cell-lysate conversion of prion protein into its protease-resistant isoform suggests the participation of a cellular chaperone. Biochem. Biophys. Res. Commun. 1999, 258, 470-475. [CrossRef] [PubMed]

96. Yokoyama, T.; Takeuchi, A.; Yamamoto, M.; Kitamoto, T.; Ironside, J.W.; Morita, M. Heparin enhances the cell-protein misfolding cyclic amplification efficiency of variant creutzfeldt-jakob disease. Neurosci. Lett. 2011, 498, 119-123. [CrossRef] [PubMed]

97. Baker, C.A.; Lu, Z.Y.; Zaitsev, I.; Manuelidis, L. Microglial activation varies in different models of creutzfeldt-jakob disease. J. Virol. 1999, 73, 5089-5097.

98. Falsig, J.; Julius, C.; Margalith, I.; Schwarz, P.; Heppner, F.L.; Aguzzi, A. A versatile prion replication assay in organotypic brain slices. Nat. Neurosci. 2008, 11, 109-117. [CrossRef]

99. Nieznanski, K. Interactions of prion protein with intracellular proteins: So many partners and no consequences? Cell. Mol. Neurobiol. 2010, 30, 653-666. [CrossRef]

(C) 2019 by the authors. Licensee MDPI, Basel, Switzerland. This article is an open access article distributed under the terms and conditions of the Creative Commons Attribution (CC BY) license (http:/ / creativecommons.org/licenses/by/4.0/). 